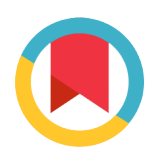

Check for updates

\title{
The progress of stem cells in the treatment of diabetes mellitus type 1
}

\section{Nihad Elsadig Babiker ${ }^{1,2, *}$, Alsadig Gassoum², Nahla E. Abdelraheem ${ }^{2,3}$, Mohamed Abdelrahman Arbab ${ }^{2,5}$, Sawsan Ahmed Hamed ALDeaf ${ }^{2}$, Mohamad Ahmed Ali El-Sheikh4 ${ }^{4}$ Hassan Hussein Musa1}

\author{
${ }^{1}$ Faculty of Medical Laboratory Sciences, University of Khartoum-Sudan \\ ${ }^{2}$ National Center of Neurological Sciences, Sudan \\ ${ }^{3}$ Faculty of Medical Laboratory Sciences, National University-Sudan \\ ${ }^{4}$ Faculty of Medicine,University of Khartoum-Sudan \\ ${ }^{5}$ Department of Surgery, Faculty of Medicine, University of Khartoum-Sudan
}

*For correspondence:

nihadelsadig@yahoo.com

Competing interests: The authors declare that no competing interests exist.

Received: 02 May 2017

Accepted: 05 June 2017

Published: 30 June 2017

Copyright The Author(s) 2017. This article is published with open access by BioMedPress (BMP).

This article is distributed under the terms of the Creative Commons Attribution License (CC-BY 4.0) which permits any use, distribution, and reproduction in any medium, provided the original author(s) and the source are credited.

\section{Abstract}

Diabetes mellitus is a major health problem in the world. The total number of diabetic's population is increasing every year. Currently used treatment of diabetes mellitus type 1 by controlling the blood sugar levels, doesn't prevent complications which associate diabetes. The stem cell based therapy for diabetes aims to replace the diseased or lost cells of the pancreas with new cells using pluripotent or multipotent stem cells. Scientists successfully produced insulin secreting cell from different types of stem cells. In this article we briefly reviewed the progress made in the stem cell research for diabetes treatment.

\section{Keywords}

Diabetes mellitus, Stem cells, Cell therapy 


\section{Introduction}

Diabetes mellitus (DM) is a group of metabolic diseases associated with high level of sugar in the blood over a prolonged period (Organization and Organization, 2011). Diabetes occurs due to lack of insulin production by pancreas or the cells of the body not responding properly to the insulin produced (Gardner and Shoback, 2011). The total number of diabetic population in 2012 were about 371 million and is expected to reach 552 million in 2030 (Abdulazeez, 2015). Type 1 diabetes mellitus is characterized by loss of insulin-producing beta cells of the islets of Langerhans in pancreas, resulting in insulin deficiency (Rother, 2007), mainly by CD8+,CD4+ and some cytokines such as IL-2 and TNF-a and so it is classified as immune-mediated or idiopathic disease (Atkinson and Maclaren, 1994). It comprises $10 \%$ of diabetes mellitus cases in North America and Europe and is Traditionally termed "juvenile diabetes" because the majority of cases were in children but can affect both children and adult. Type 1 diabetes can be accompanied by irregular and unpredictable high blood sugar levels with ketosis, and sometimes with low blood sugar levels (Dorner et al., 1977). It is partly inherited with multiple genes including certain HLA genotypes. In genetically susceptible people the onset of diabetes can be triggered by one or more environmental factors such as viral infection or diet (Risérus et al., 2009). All forms of diabetes increase the risk of long-term complications develop after many years (O'Gara et al., 2013). The major complications are cardiovascular disease, coronary artery disease, stroke peripheral vascular disease retinopathy, nephropathy and neuropathy ( $\mathrm{O}^{\prime} \mathrm{G}$ ara et al., 2013; Organization and Organization, 2011; Sarwar et al., 2010). All forms of medications for diabetics are to avoid or minimize chronic diabetic complications occur by hyperglycemia or hypoglycemia. The most common medication is hypoglycemic treatment either oral hypoglycemic or insulin therapy (Goswami et al., 2014). Patients with type 1 diabetes mellitus require direct injection of insulin because their bodies cannot produce enough or even any insulin (Daneman, 2006), but insulin therapy creates risk because of the inability to continuously know a person's blood glucose level and adjust insulin infusion appropriately (Organization and Organization, 2011). Since 2010 there is no other clinically available form of insulin administration other than injection for patients with type 1. However, there are some insulin application mechanisms under experimental development since 2004, including a capsule that passes to the liver and delivers insulin into the bloodstream (Daneman, 2006). And Vaccines for type I using glutamic acid decarboxylase (GAD), but these are currently not being tested by the pharmaceutical companies (Aanstoot et al., 2007). Data from 1994 to 2007 was analyzed and it revealed that the mean number of diabetes medications per treated patient increased from 1.14 in 1994 to 1.63 in 2007 (Soltesz et al., 2007). 


\section{Pancreas transplantation}

Pancreas transplant can restore proper glucose regulation (Larsen, 2004). According to the International Pancreatic Transplant Registry up to December 31st, 2010, more than 35 thousand pancreas transplants had been done. The primary complication related to pancreatic graft loss is technical failure, surgical complications, metabolic complications like acidosis and dehydration intestinal leak,infectious complications (Meirelles Junior et al., 2015) and accompanying immunosuppressant required after transplantation may be more dangerous than continued insulin replacement therapy. Pancreas transplantation is efficient in people with extremely labile type 1 diabetes mellitus (Armita Mahdavi Gorabi, 2016).

\section{Islet cell transplantation}

Islet cell transplantation may be a good option in those people with type 1 diabetes poorly controlled with insulin (Bottazzo et al., 1974). Difficulties include finding of compatible donors, getting the new islets to survive and the side effects of medications used to prevent rejection (Naujok et al., 2008). Success rates of technology were $44 \%$ of transplant did not use insulin for 3 years (Bottazzo et al., 1974). The Edmonton group in 2000 established the "Edmonton Protocol" and demonstrated sustained long-term insulin-independence (Powers, 2008). The islet cells were isolated from cadaveric donors (Azarpira et al., 2014), and injected into the recipient's portal vein. The initial beta cell mass was reduced due to instant blood mediated inflammatory reactions, immune reaction to transplanted cells and diabetogenic effect of immunosuppressive drugs. Therefore, repeated episodes of cell transplantation was needed to achieve good results (Agarwal and Brayman, 2012). Multiple transplants are needed to reduce insulin shots because a thrombotic reaction occurs immediately when isolated islets are exposed to ABO compatible blood (Bennet et al., 1999). Blood clots entrapping islets may impaire insulin production of the transplanted islets due to shutting them off from oxygen and to attracting immunocytes (Bennet et al., 2000).Therefore, Scientists explore the possibilities to generate pancreatic cell from stem cell. The stem cell based therapy for diabetes aims to replace the diseased or lost cells of the pancreas using pluripotent or multipotent stem cells (Abdulazeez, 2015).

\section{Stem cells}

Stem cells are highly specialized cells that make up the body tissues and organs. During life the body continues to rely on stem cells to replace injured tissues and cells that are lost every day. Stem cells have ability to self-renew and differentiation (Slack, 2000). Different types of stem cells such as embryonic stem cells, mesenchymal stem cells and induced pluripotent stem cells (IPS), had been successfully differentiated to insulin producing cells (Soria et al., 2000) (Fig. 1). 
Embryonic stem cells (ESC) are isolated from blastocysts and can differentiate into endoderm, mesoderm and ectoderm cells. They can also differentiate in to insulin producing cell, these cells are able to release insulin in response to glucose stimuli and to normalize the blood glucose levels when transplanted into the diabetic mice (Naujok et al., 2008). Human ESCs can be differentiated into endocrine cells but there is a risk of promoting the development of tumors (Kroon et al., 2008). Groups of researchers used mouse and human ESCs and indicated final cell homogeneity, immaturity of the differentiated cell, low numbers of insulin-producing cells and a poor insulin response when the cells were exposed to glucose (Abdulazeez, 2015). Using human ESC-derived pancreatic precursor cells to treat patients with T1D is on experiment where the cells are encapsulated in a drug delivery system developed by the Encaptra Company. The system is administered under the patient's skin to be protected from the recipient's immune cells (llic et al., 2015).

Due to the nature of its origin, the ESCs are the target for the ethicists, since they are derived from unused or unfertilized embryos at in vitro fertilization clinics which should be on the basis of informed consent of donor before using them for any clinical study. However, in most of the cases the cells from the embryo are obtained by destroying the embryo which raises a question about the origin of life and ethical rights to destroy the embryo (Abdulazeez, 2015).

\section{Induced Pluripotent Stem Cells}

The discovery of induced pluripotent stem cells (iPSCs) in 2006 opened a new possibility in generating replacement cell based therapy (Takahashi and Yamanaka, 2006). IPSCs like ESCs have infinite self-renewal capacity and great potential to differentiate into a wide variety of cell types (Yu et al., 2007). Undifferentiated iPSCs can be maintained as cell lines; this provides great promise for disease modeling and allowing the generation of personalized stem cells for autologous cell therapies (Jang et al., 2012). Mouse skin fibroblast-derived iPSCs were able to differentiate into $\beta$-like cells, similar to normal, endogenous insulinsecreting cells that managed to control hyperglycemia in diabetic mice (Alipio et al., 2010). The human ESCs and iPSCs were differentiated into mature pancreatic cells which were capable of secreting insulin and C-peptide (Zhang et al., 2009). The iPSCs have been produced from patients with T1D and T2D (Teo et al., 2013). Insulin-producing cells have then been produced in vitro from iPSCs by directed differentiation, using small molecules and growth factors in culture (Raikwar et al., 2015). The advantage of using iPSCs is the absence of ethical concerns, and low risk of teratoma formation (Kanemura et al., 2014).

The disadvantage of iPSCs is the reprogramming of somatic cells into iPSCs which is usually obtained by using viral transfection of transcription factors. The major limitation of this technology is the use of harmful genome which can cause mutations and prevent the normal function of iPSCs, their differentiation ability and may cause tumorigenesis (Calafiore and Basta, 2015). 


\section{Mesenchymal stem cells}

Friedenstein was the first person describes the isolation of MSCs from rat bone marrow (BM) (Zhao et al., 2016). Besides BM, MSCs can also be isolated from adipose tissues, fetal liver, cord blood, mobilized peripheral blood, fetal lung, placenta, umbilical cord, dental pulp, synovial membrane (Nagamura-Inoue and $\mathrm{He}, 2014)$, periodontal ligament, endometrium, trabecular and compact bone (Dominici et al., 2006). The International Society for Cellular Therapy (ISCT) has offered several minimal criteria to identify MSCs which are; Plastic adherent fibroblast-like growth. Expression of CD73, CD90 and CD105 markers in at least $95 \%$ of cell population and lack the expression of CD34, CD45, CD14, CD11b, CD19 or CD79a and HLA-II markers, in addition to in vitro differentiation capability (Dominici et al., 2006). Under appropriate culture conditions MSCs are able to differentiating into mesodermal, endodermal and even ectodermal cells. They have the ability to release growth factors and transplantation immunoprotective cytokines. MSCs can be used for tissue regeneration and repair because they don't form teratoma. Easy isolation, high quantity expansion and multipotential differentiation of MSCs make them ideal candidate for stem cell-based therapy and their application as gene carrier while their. Ablility to escape immune recognition and inhibit immune responses make them a very promising tool for immunomodulatory cell therapy in immune mediated diseases. There are currently 423 clinical trials using MSCs registered at clinicaltrials.gov. The clinical trials have been conducted for tissue repair including cardiac ischemia, limb ischemia, amyotrophic lateral sclerosis, diabetes, ischemic stroke, osteoarthritis, liver cirrhosis and liver failure (Zhao et al., 2016). In these study human MSCs was intravenously introduced to NOD/SCID mice with total body irradiation or local abdominal or leg irradiation and the long term sideeffect were investigated. They concluded that MSCs injection is safe and efficient for long-term treatment of severe complications after radiotherapy (Francois et al., 2014).

MSCs have also been injected directly in the pancreas and being niche providing cells, these have helped alleviate diabetes symptoms by improving metabolic control in animal models counteracting autoimmunity, enhancing islet engraftment and survival or as a source of growth factors and cytokines ( $\mathrm{Xu}$ et al., 2009). Injection of MSCs not only helps to improve pancreatic functions, but also heals associated symptoms like diabetic foot, nephropathy, neuropathy, etc. Although the effect of MSCs appears to be more generalized and most probably is a niche effect rather than true regeneration (Bhartiya, 2016).

Spontaneous differentiation of MSCs in the host tissue is rare, therefore therapeutic use of MSCs depends on the ability to control their in vivo differentiation into functional cells with high efficiency and purity. An additional limitation is the potential of MSCs to differentiate into unwanted mesenchymal lineages, which may impair their therapeutic use. Several studies suggested the restriction of such unwanted differentiation by a variety of factors, however, this problem is still unsolved because the exact roles of these factors are not 
completely understood. Possible malignant transformation and cytogenetic aberrations of MSCs is also an Additional limitation (Volarevic et al., 2011).

\section{MSCs from Bone marrow}

MSC is another cellular component of the BM and essential HSC niche component. Human BM-derived MSCs can be cultured long-term in vitro without losing their morphologic, phonotypical functional characteristics and with normal karyotype up to 44 weeks (Welsh et al., 1988). T cell-mediated immune response against newly-formed $\beta$ cells is inhibited by MSCs from BM. Thus, stem cell therapy may be the best approach for treating T1DM patients ( $\mathrm{Li}$ and Ikehara, 2014). Stem cells move to the damaged site, differentiate and induce structural and functional repair that help in cure of diabetes and normalize insulin level in the body (Armita Mahdavi Gorabi, 2016). In an in vivo experiment the mouse bone marrow cells were differentiated into functioning bcells (lanus et al., 2003). Other experiment found that IPC from BM-MSC rat normalized chronic hyperglycemia in diabetic rat (Armita Mahdavi Gorabi, 2016).

\section{MSCs from Adipose Tissue}

Adipose tissues isolated from human lipoaspirates, also called adipose-derived stromal cells (ADSCs) can be accessed easily in large amounts and have differentiation capacities similar to BMMSCs. The harvesting and producing of AD-MSCs are more practical and less invasive in humans compared with BMMSCs, and can be considered as an alternative source of IPCs. AD-MSCs when cultured in media containing fibroblast growth factor expressed markers like Is 1 mRNA, which is essential for the generation of pancreatic islet cells (Dang et al., 2015). Several studies indicated that AD-MSCs from murine epididymis have the potentiality to differentiate into insulin-producing cells, which expressed PDX1, Ngn3 NeuroD, Pax4, Glut2, and secreted insulin and Cpeptide. Recent study showed that AD-MSCs were differentiated into IPCs after 38-day co-culture with islet cells. The merging of differentiated AD-MSCs and islet cells resulted in better recovery from diabetes compared to islets transplants alone or co-transplantation of islets and differentiated BMMSCs (Hashemian et al., 2015) (Table 1).

\section{MSCs from Human Placenta}

Human Placenta-Derived MSCs (hPDMSCs) is an alternative source for cell therapy in diabetes (Kadam et al., 2010). Cells isolated from human chorionic villi of full-term placenta can form islet-like cell clusters (ILCs). Differentiated ILCs were found to express human insulin glucagon and somatostatin by immunocytochemistry. Transplantation of hPDMSCs or ILCs derived hPDMSCs in STZ-induced diabetic mice led to restoration of normoglycemia (Ende et al., 2004). 


\section{MSCs from Human Cord Blood and Human umbilical cord blood (UCB)}

MSCs isolated from cord blood (Bieback et al., 2004) and hUCB-derived USSCs (unrestricted somatic stem cells) has a potentiality to differentiate into IPCs with same cell markers and properties as MAPCs (multipotent adult progenitor cells) (Ende et al., 2004; Koblas et al., 2005). The mononuclear adherent cells isolated from UCB show a BMMSCs-like immunophenotype and differentiation capacities.UCB cells exhibit genes essential for differentiation into pancreatic endocrine tissue (Is|1, PDX1, Pax4, and Ngn3) after culture in a medium supplemented with no specific cytokines or growth factors except fetal calf serum (Hashemian et al., 2015). UCB-MSCs-derived IPCs released insulin and Cpeptide in response to a glucose challenge in vitro and in vivo (Prabakar et al., 2012). Improve in glycaemic profiles associated with histological improvement of insulates were achieved after intravenous (IV) administration of hUCB-MSCs to 25 NOD type 1 diabetic mice with insulitis.UCB-MSCs are available in large amounts, with low risk for immune rejection and have increased capacities for expansion and differentiation into IPCs can be considered as an alternative option for treatment of diabetes (Hashemian et al., 2015).

\section{MSCs from Wharton's Jelly}

MSCs in umbilical cord Wharton's jelly (WJ) share the same capability of MSC from UCB to differentiate into IPC. Researchers successfully differentiate WJMSCs into IPCs and transplanted the IPCs into the liver of the diabetic mice. They demonstrated the expression of insulin in response to physiological glucose levels, as well as secretion of $\mathrm{C}$-peptide and expression of pancreasspecific genes PDX1, Nkx2.2, HLXB-9, and Glut-2 (Hashemian et al., 2015). Later scientist compared the differentiation ability of WJ-MSCs and BMMSCs in obtaining IPCs phenotype. They indicated that both cellular types were able to form islet-like clusters on the first day in a preconditioned culture medium. In addition, they found a higher expression of PDX1 in differentiated WJMSCs compared with the differentiated BMMSCs, and the secretion of insulin and mRNA expression of insulin and C-peptide were higher in the differentiated WJMSCs. The WJ-MSCs infected with PDX1gene carrying recombinant adenovirus and then treated with inductive factors, could differentiate into IPCs in vitro. The differentiated cells expressed $\beta$-cell related genes like PDX1, Ngn3, Glut2, and $\mathrm{Nkx6.1}$ and were able correspond to high concentrations of glucose (Wu et al., 2009). Another study demonstrated that WJ-MSCs differentiate into IPCs through a three-stage inductive protocol. They also showed that $\beta$-cell related genes were expressed in both differentiated cells and $\beta$-like cells transplanted in to the liver of STZ-induced diabetic rats through portal vein. As a result blood glucose levels were significantly reduced 4weeks after transplantation (He et al., 2011). The differentiated IPCs from human WJ-MSCs could alleviate hyperglycemia in diabetic mice (Tsai et al., 2012). These promising data suggest that WJ-MSCs possess the ability both in vitro and in vivo to differentiate into insulin-secreting cells. Due to more similarities of hUCB-MSCs, hPDMSCs, and WJ-MSCs to embryonic stem cells (ESCs), these groups of MSCs should be 
considered as potential cell therapy options rather than BMMSCs. With respect to the outstanding differentiation and immunomodulatory capacities of WJMSCs, conducting a banking system for both autologous and allogenic transplantation of these cells should be taken into consideration (Hashemian et al., 2015) (Table 1.).

\section{Table 1. Results of some MSCs clinical trials in Diabetes Mellitus type 1}

\begin{tabular}{|c|c|c|}
\hline Types of MSC & Routes of Transplantation & Out come \\
\hline Human MSCs & $\begin{array}{l}\text { Intravenously introduced to NOD/ } \\
\text { SCID mice with total body } \\
\text { irradiation or local abdominal or leg } \\
\text { irradiation }\end{array}$ & $\begin{array}{l}\text { Safe and efficient for long -term } \\
\text { treatment of severe complication after } \\
\text { radiotherapy } \\
\text { (Francois et al.,2014) }\end{array}$ \\
\hline MSCS & injected directly in the pancreas & $\begin{array}{l}\text { Improvement of metabolic control } \\
\text { Enhancement of islet engraftment and } \\
\text { survival (Xu et al.,2009) }\end{array}$ \\
\hline BM-MSC & $\begin{array}{l}\text { BM-MSC differentiated In-vivo into } \\
\text { functioning b-cells and }\end{array}$ & $\begin{array}{l}\text { Normalization of chronic hyperglycemia } \\
\text { in diabetic rat (Tang et al., 2007) }\end{array}$ \\
\hline hPDMSCs) & $\begin{array}{l}\text { Differentiated into islet-like cell } \\
\text { clusters and Transplanted into STZ- } \\
\text { induced diabetic mice }\end{array}$ & $\begin{array}{l}\text { Restoration of normoglycemia in diabetic } \\
\text { mice (Ende et al.,2004) }\end{array}$ \\
\hline hUCB-MSCs & $\begin{array}{l}\text { Differentiated into IPC and IV } \\
\text { administration }\end{array}$ & $\begin{array}{l}\text { Improve in glycaemic profiles, histological } \\
\text { improvement of insulates (Hashemian et } \\
\text { al.,2015). }\end{array}$ \\
\hline \multirow{3}{*}{ WJ-MSCs } & $\begin{array}{l}\text { 1-Differentiated into IPC and } \\
\text { transplanted into } \\
\text { the liver }\end{array}$ & $\begin{array}{l}\text { Expression of insulin } \\
\text { Secretion of C-peptide } \\
\text { Expression of pancreas-specific genes } \\
\text { (Hashemian et al.,2015) }\end{array}$ \\
\hline & $\begin{array}{l}\text { 2-Infected with PDX1gene and } \\
\text { differentiated to IPC }\end{array}$ & $\begin{array}{l}\text { Correspondence to high concentrations } \\
\text { of glucose (Wu et al., 2009) }\end{array}$ \\
\hline & $\begin{array}{l}\text { 3-Differentiated into IPC and } \\
\text { transplanted in to the liver of STZ- } \\
\text { induced diabetic rats }\end{array}$ & $\begin{array}{l}\text { Reduction of blood glucose levels after } \\
\text { 4weeks of transplantation (He et al.,2011) }\end{array}$ \\
\hline
\end{tabular}

\section{Pancreatic Stem Cells}

Several studies suggested that pancreatic stem or progenitor cells existing within pancreatic duct cells are able to differentiate and migrate to form new islets during both organogenesis and regeneration (Tateishi et al., 2008). Stem cells isolated from pancreas can differentiate into osteogenic chondrogenic, and adipogenic lineages as well as expressing PDX1, Pax4, and Ngn3 transcription factors and have the potential to derive beta cells (Seeberger et al., 2006). Similarly pancreatic stem cells were successfully isolated from adult human pancreatic duct; these cells not only express nestin and PDX1 but also exhibit the identical markers of MSCs. In an earlier study it was shown that fibroblast-like 
cells residing in pancreas are multipotent cells capable of reversible endoderm mesoderm transition (EMT) just like MSCs. The endoderm mesoderm transition does not underlie the appearance of fibroblast-like cells in mouse islet cultures but that fibroblast-like cells appear to represent MSC-like cells akin to MSCs isolated from bone marrow (Hashemian et al., 2015).

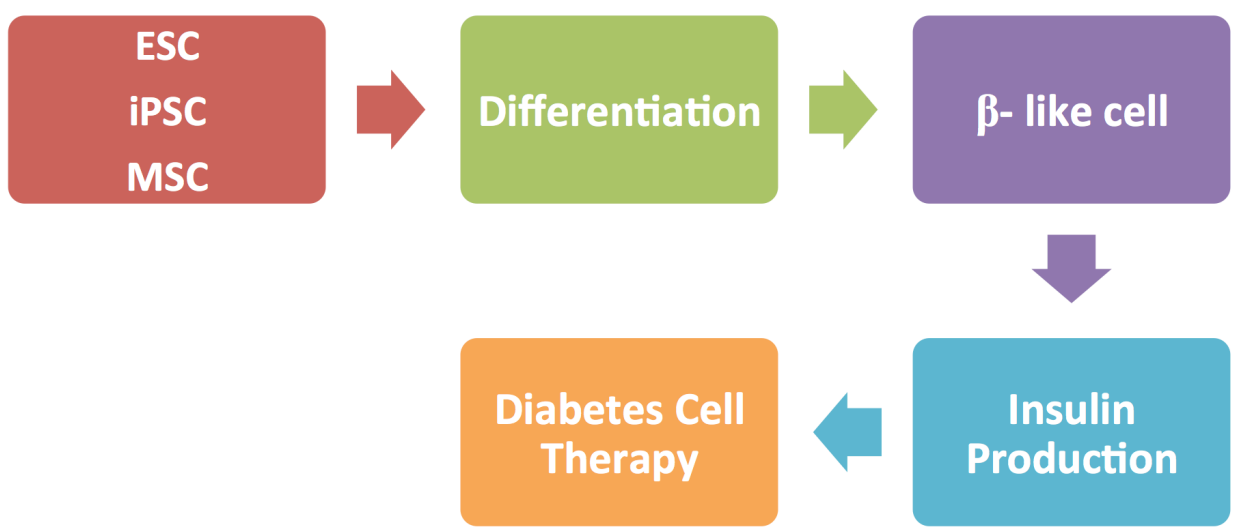

Figure 1. The role of stem cells in diabetes therapy using embryonic stem cell (ESC), induced pluripotent stem cells (iPSC), mesenchymal stem cell (MSC).

\section{Conclusions}

The clinical trials have demonstrated the effectiveness of MSCs in the treatment of T1D. Despite the success of differentiation of human MSCs in vitro into functional pancreatic cells the rate of trans-differentiation was considered low and the duration of functional maintenance in vivo is difficult to evaluate. The absence of standardized protocols for the expansion and generation of insulin secreting cells still leads to in consistent clinical outcomes. These interesting finding may provide a new insight into the use of MSCs based therapy for diabetes.

\section{Abbreviations}

ADSCs Adipose-derived stromal cells

BM Bone marrow

BMMSCs Bone marrow mesenchymal stem cells

DM Diabetes mellitus

EMT Endoderm mesoderm transition

ESC Embryonic stem cells 


\section{Progress in \\ S TE M C E L L}

ISSN: 2199-4633

www.cellstemcell.org

GAD Glutamic acid decarboxylase.

HPDMSCs Human Placenta-Derived MSCs

HSC Hematopoietic stem cell

ILCs islet-like cell clusters

IPCs Insulin producing cells.

iPS induced pluripotent stem cells

ISCT International Society for Cellular Therapy

IV Intravenous

MAPCs Multipotent adult progenitor cells.

MSC Mesenchymal stem cell

STZ Streptozotocin

T1D Diabetes mellitus type 1

UCB Human umbilical cord blood.

USSCs unrestricted somatic stem cells

WJ Wharton's jelly

\section{Acknowledgment}

The authors acknowledge the staff of the National Center of Neurological Sciences, Sudan for their helpful and support.

\section{Author Contribution}

All authors equally contributed to this manuscript, included wrote, corrected and approved this manuscript. 
ISSN: 2199-4633 www.cellstemcell.org

\section{References}

Aanstoot, H.-J., Anderson, B.J., Daneman, D., Danne, T., Donaghue, K., Kaufman, F., Réa, R.R., and Uchigata, Y. (2007). The global burden of youth diabetes: Perspectives and potential: A charter paper. Pediatr Diabetes 8, 4-40.

Abdulazeez, S.S. (2015). Diabetes treatment: A rapid review of the current and future scope of stem cell research. Saudi Pharmaceutical Journal 23, 333-340.

Agarwal, A., and Brayman, K.L. (2012). Update on islet cell transplantation for type 1 diabetes. Paper presented at: Seminars in interventional radiology (Thieme Medical Publishers).

Alipio, Z., Liao, W., Roemer, E.J., Waner, M., Fink, L.M., Ward, D.C., and Ma, Y. (2010). Reversal of hyperglycemia in diabetic mouse models using induced-pluripotent stem (iPS)-derived pancreatic $\beta$-like cells. Proceedings of the National Academy of Sciences 107, 13426-13431.

Armita Mahdavi Gorabi, A., Farhad, Souri, Mona, Jahandideh, Kazempor (2016). Mesenchymal Stem Cells (M.S.C.) Effect in Streptozotocin (STZ) Induced Type I Diabetic Rats. The Caspian Sea Journal 1, 91-95.

Atkinson, M.A., and Maclaren, N.K. (1994). The pathogenesis of insulin-dependent diabetes mellitus. New England Journal of Medicine 331, 1428-1436.

Azarpira, N., Aghdai, M.H., Nikeghbalian, S., Geramizadeh, B., Darai, M., Esfandiari, E., Bahador, A., Kazemi, K., Al-Abdullah, I.H., and Malek-Hosseini, S.A. (2014). Human islet cell isolation: the initial step in an islet transplanting program in Shiraz, Southern Iran. Experimental and clinical transplantation: official journal of the Middle East Society for Organ Transplantation 12, 139-142.

Bennet, W., Groth, C.-G., Larsson, R., Nilsson, B., and Korsgren, O. (2000). Isolated human islets trigger an instant blood mediated inflammatory reaction: implications for intraportal islet transplantation as a treatment for patients with type 1 diabetes. Upsala journal of medical sciences 105, 125-133.

Bennet, W., Sundberg, B., Groth, C.-G., Brendel, M.D., Brandhorst, D., Brandhorst, H., Bretzel, R.G., Elgue, G., Larsson, R., and Nilsson, B. (1999). Incompatibility between human blood and isolated islets of Langerhans: a finding with implications for clinical intraportal islet transplantation? Diabetes 48, 1907-1914.

Bhartiya, D. (2016). Stem cells to replace or regenerate the diabetic pancreas: Huge potential \& existing hurdles. The Indian journal of medical research 143, 267.

Bieback, K., Kern, S., Klüter, H., and Eichler, H. (2004). Critical parameters for the isolation of mesenchymal stem cells from umbilical cord blood. Stem cells 22, 625-634.

Bottazzo, G., Florin-Christensen, A., and Doniach, D. (1974). Islet-cell antibodies in diabetes mellitus with autoimmune polyendocrine deficiencies. The Lancet 304, 1279-1283.

Calafiore, R., and Basta, G. (2015). Stem cells for the cell and molecular therapy of type 1 diabetes mellitus (T1D): the gap between dream and reality. American journal of stem cells 4, 22.

Daneman, D. (2006). Type 1 diabetes. The Lancet 367, 847-858.

Dang, L.T.-T., Bui, A.N.-T., Pham, V.M., Phan, N.K., and Van Pham, P. (2015). Production of islet-like insulin-producing cell clusters in vitro from adiposederived stem cells. Biomedical Research and Therapy 2, 1-9. 


\section{Progress in \\ STEM C E L L}

ISSN: 2199-4633

www.cellstemcell.org

Dominici, M., Le Blanc, K., Mueller, I., Slaper-Cortenbach, I., Marini, F., Krause, D., Deans, R., Keating, A., Prockop, D., and Horwitz, E. (2006). Minimal criteria for defining multipotent mesenchymal stromal cells. The International Society for Cellular Therapy position statement. cytotherapy 8, 315-317.

Dorner, M., Pinget, M., and Brogard, J.M. (1977). [Essential labile diabetes (author's transl)]. MMW, Munchener medizinische Wochenschrift 119, 671-674.

Ende, N., Chen, R., and Reddi, A.S. (2004). Transplantation of human umbilical cord blood cells improves glycemia and glomerular hypertrophy in type 2 diabetic mice. Biochemical and biophysical research communications 321, 168-171.

Francois, S., Usunier, B., Douay, L., Benderitter, M., and Chapel, A. (2014). Long-Term Quantitative Biodistribution and Side Effects of Human Mesenchymal Stem Cells (hMSCs) Engraftment in NOD/SCID Mice following Irradiation. Stem cells international $2014,939275$.

Gardner, D., and Shoback, D. (2011). Pancreatic hormones and diabetes mellitus. Greenspan's Basic \& Clinical Endocrinology 9th ed New York, NY: The McGraw-Hill Companies.

Goswami, S.K., Vishwanath, M., Gangadarappa, S.K., Razdan, R., and Inamdar, M.N. (2014). Efficacy of ellagic acid and sildenafil in diabetes-induced sexual dysfunction. Pharmacognosy magazine 10, S581-587.

Hashemian, S.J., Kouhnavard, M., and Nasli-Esfahani, E. (2015). Mesenchymal stem cells: rising concerns over their application in treatment of type one diabetes mellitus. Journal of diabetes research 2015.

He, D., Wang, J., Gao, Y., and Zhang, Y. (2011). Differentiation of PDX1 gene-modified human umbilical cord mesenchymal stem cells into insulin-producing cells in vitro. International journal of molecular medicine 28, 1019-1024.

lanus, A., Holz, G.G., Theise, N.D., and Hussain, M.A. (2003). In vivo derivation of glucose-competent pancreatic endocrine cells from bone marrow without evidence of cell fusion. The Journal of clinical investigation 111, 843-850.

Ilic, D., Devito, L., Miere, C., and Codognotto, S. (2015). Human embryonic and induced pluripotent stem cells in clinical trials. British medical bulletin 116, 19-27.

Jang, J., Yoo, J.E., Lee, J.A., Lee, D.R., Kim, J.Y., Huh, Y.J., Kim, D.S., Park, C.Y., Hwang, D.Y., Kim, H.S., et al. (2012). Disease-specific induced pluripotent stem cells: a platform for human disease modeling and drug discovery. Experimental \& molecular medicine 44, 202-213.

Kadam, S., Muthyala, S., Nair, P., and Bhonde, R. (2010). Human placenta-derived mesenchymal stem cells and islet-like cell clusters generated from these cells as a novel source for stem cell therapy in diabetes. Rev Diabet Stud 7, 168-182.

Kanemura, H., Go, M.J., Shikamura, M., Nishishita, N., Sakai, N., Kamao, H., Mandai, M., Morinaga, C., Takahashi, M., and Kawamata, S. (2014). Tumorigenicity studies of induced pluripotent stem cell (iPSC)-derived retinal pigment epithelium (RPE) for the treatment of age-related macular degeneration. PloS one 9, e85336.

Koblas, T., Harman, S.M., and Saudek, F. (2005). The application of umbilical cord blood cells in the treatment of diabetes mellitus. Rev Diabet Stud 2, 228-234.

Kroon, E., Martinson, L.A., Kadoya, K., Bang, A.G., Kelly, O.G., Eliazer, S., Young, H., Richardson, M., Smart, N.G., and Cunningham, J. (2008). Pancreatic endoderm derived from human embryonic stem cells generates glucose-responsive insulin-secreting cells in vivo. Nature biotechnology 26, 443-452. 


\section{Progress in \\ STEM C E L L}

ISSN: 2199-4633 www.cellstemcell.org

Larsen, J.L. (2004). Pancreas transplantation: indications and consequences. Endocrine Reviews 25, 919-946.

Li, M., and Ikehara, S. (2014). Stem cell treatment for type 1 diabetes. Frontiers in cell and developmental biology 2, 9 .

Meirelles Junior, R.F., Salvalaggio, P., and Pacheco-Silva, A. (2015). Pancreas transplantation: review. Einstein (Sao Paulo, Brazil) 13, 305-309.

Nagamura-Inoue, T., and He, H. (2014). Umbilical cord-derived mesenchymal stem cells: their advantages and potential clinical utility. World J Stem Cells 6, 195-202.

Naujok, O., Francini, F., Picton, S., Jörns, A., Bailey, C.J., and Lenzen, S. (2008). A new experimental protocol for preferential differentiation of mouse embryonic stem cells into insulin-producing cells. Cell transplantation 17, 1231-1242.

O'Gara, P.T., Kushner, F.G., Ascheim, D.D., Casey, D.E., Chung, M.K., De Lemos, J.A., Ettinger, S.M., Fang, J.C., Fesmire, F.M., and Franklin, B.A. (2013). 2013 ACCF/AHA guideline for the management of ST-elevation myocardial infarction. Circulation 127, e362-e425.

Organization, W.H., and Organization, W.H. (2011). Diabetes fact sheet No. 312. URL: http://www who int/mediacentre/factsheets/fs312/en/index html [accessed 2013-03-01][WebCite Cache].

Powers, A.C. (2008). Insulin therapy versus cell-based therapy for type 1 diabetes mellitus: what lies ahead? Nature clinical practice Endocrinology \& metabolism 4, 664-665.

Prabakar, K.R., Domínguez-Bendala, J., Molano, R.D., Pileggi, A., Villate, S., Ricordi, C., and Inverardi, L. (2012). Generation of glucose-responsive, insulin-producing cells from human umbilical cord blood-derived mesenchymal stem cells. Cell transplantation 21, 1321-1339.

Raikwar, S.P., Kim, E.-M., Sivitz, W.I., Allamargot, C., Thedens, D.R., and Zavazava, N. (2015). Human iPS cell-derived insulin producing cells form vascularized organoids under the kidney capsules of diabetic mice. PloS one 10, e0116582.

Risérus, U., Willett, W.C., and Hu, F.B. (2009). Dietary fats and prevention of type 2 diabetes. Progress in lipid research 48, 44-51.

Rother, K.I. (2007). Diabetes treatment-bridging the divide. The New England journal of medicine 356, 1499.

Sarwar, N., Gao, P., Seshasai, S.R., Gobin, R., Kaptoge, S., Di Angelantonio, E., Ingelsson, E., Lawlor, D.A., Selvin, E., Stampfer, M., et al. (2010). Diabetes mellitus, fasting blood glucose concentration, and risk of vascular disease: a collaborative meta-analysis of 102 prospective studies. Lancet (London, England) 375, 2215-2222.

Seeberger, K.L., Dufour, J.M., Shapiro, A.M.J., Lakey, J.R., Rajotte, R.V., and Korbutt, G.S. (2006). Expansion of mesenchymal stem cells from human pancreatic ductal epithelium. Laboratory investigation 86, 141-153.

Slack, J.M. (2000). Stem cells in epithelial tissues. Science 287, 1431-1433.

Soltesz, G., Patterson, C., and Dahlquist, G. (2007). Worldwide childhood type 1 diabetes incidence-what can we learn from epidemiology? Pediatric diabetes 8, 6-14.

Soria, B., Roche, E., Berna, G., León-Quinto, T., Reig, J.A., and Martín, F. (2000). Insulinsecreting cells derived from embryonic stem cells normalize glycemia in streptozotocin-induced diabetic mice. Diabetes 49, 157-162. 


\section{Progress in \\ STEM C E L L}

ISSN: 2199-4633 www.cellstemcell.org

Takahashi, K., and Yamanaka, S. (2006). Induction of pluripotent stem cells from mouse embryonic and adult fibroblast cultures by defined factors. cell 126, 663-676.

Tateishi, K., He, J., Taranova, O., Liang, G., D'Alessio, A.C., and Zhang, Y. (2008). Generation of insulin-secreting islet-like clusters from human skin fibroblasts. Journal of Biological Chemistry 283, 31601-31607.

Teo, A.K., Windmueller, R., Johansson, B.B., Dirice, E., Njolstad, P.R., Tjora, E., Raeder, H., and Kulkarni, R.N. (2013). Derivation of human induced pluripotent stem cells from patients with maturity onset diabetes of the young. Journal of Biological Chemistry 288, 5353-5356.

Tsai, P.-J., Wang, H.-S., Shyr, Y.-M., Weng, Z.-C., Tai, L.-C., Shyu, J.-F., and Chen, T.-H. (2012). Transplantation of insulin-producing cells from umbilical cord mesenchymal stem cells for the treatment of streptozotocin-induced diabetic rats. Journal of biomedical science 19, 47.

Volarevic, V., Arsenijevic, N., Lukic, M.L., and Stojkovic, M. (2011). Concise review: Mesenchymal stem cell treatment of the complications of diabetes mellitus. Stem Cells 29, 5-10.

Welsh, M., Welsh, N., Nilsson, T., Arkhammar, P., Pepinsky, R.B., Steiner, D.F., and Berggren, P.-O. (1988). Stimulation of pancreatic islet beta-cell replication by oncogenes. Proceedings of the National Academy of Sciences 85, 116-120.

Wu, L.-F., Wang, N.-N., Liu, Y.-S., and Wei, X. (2009). Differentiation of Wharton's jelly primitive stromal cells into insulin-producing cells in comparison with bone marrow mesenchymal stem cells. Tissue Engineering Part A 15, 2865-2873.

Xu, J., Liao, W., Gu, D., Liang, L., Liu, M., Du, W., Liu, P., Zhang, L., Lu, S., and Dong, C. (2009). Neural ganglioside GD2 identifies a subpopulation of mesenchymal stem cells in umbilical cord. Cellular Physiology and Biochemistry 23, 415-424.

Yu, J., Vodyanik, M.A., Smuga-Otto, K., Antosiewicz-Bourget, J., Frane, J.L., Tian, S., Nie, J., Jonsdottir, G.A., Ruotti, V., and Stewart, R. (2007). Induced pluripotent stem cell lines derived from human somatic cells. science 318, 1917-1920.

Zhang, D., Jiang, W., Liu, M., Sui, X., Yin, X., Chen, S., Shi, Y., and Deng, H. (2009). Highly efficient differentiation of human ES cells and iPS cells into mature pancreatic insulinproducing cells. Cell research 19, 429-438.

Zhao, Q., Ren, H., and Han, Z. (2016). Mesenchymal stem cells: Immunomodulatory capability and clinical potential in immune diseases. Journal of Cellular Immunotherapy 2, 3-20. 